\title{
How central bankers learned to love financialization: The Fed, the Bank, and the enlisting of unfettered markets in the conduct of monetary policy
}

\author{
Timo Walter ${ }^{1}$ and Leon Wansleben ${ }^{2, *}$ \\ ${ }^{1}$ Staatswissenschaftliche Fakultät, Universität Erfurt, Nordhäuser Straße 63, Erfurt, Germany; \\ ${ }^{2}$ Max Planck Institute for the Study of Societies, Paulstr. 3, Cologne, Germany \\ *Correspondence: Iw@mpifg.de
}

\begin{abstract}
Central banks' role in financialization has received increasing attention in recent years. These debates have predominantly revolved around authorities' 'benign neglect' of asset bubbles, their deregulatory policies, and the safety nets they provide for speculative exuberance. Most analyses refer to the dominance of pro-market interests and ideas to explain these actions. The present article moves beyond these accounts by showing how an alignment between techniques of monetary governance and 'unfettered' financial markets can explain central banks' endorsement of increasingly fragile structures of liquidity and their strategic ignorance towards growing amounts of debt. We analyze the processes of abstraction and formalization by which the 'programmes' and 'technologies' of monetary governance have been made compatible with the texture of contemporary finance; and we show how central banks' attempts to make markets more amenable to their methods of policy implementation shaped new conduits for financial growth. As empirical cases, we discuss the Federal Reserve's experiments with different policy frameworks in the 1980s and the Bank of England's twisted path to inflation targeting from 1979 to 1997. These cases allow us to demonstrate that the infrastructural power of contemporary central banking is predicated on the same institutional foundations that have made financialization possible.
\end{abstract}

Key words: Institutional change, financialization, neo-liberalism, capitalist system, financial crisis

JEL classification: B2 History of Economic Thought since 1925, N2 Financial Markets and Institutions, P1 Capitalist Systems 


\section{Introduction}

Scholars in political economy and economic sociology widely assume that financialization and the rise of neoliberalism are closely intertwined processes. Greta Krippner's (2011) seminal analysis of institutional changes in the US since the 1970s has become a benchmark for understanding these entangled histories. Along the lines of her work, recent scholarship tends to portray the neoliberalism-finance nexus in terms of a recursive process: deregulatory and pro-market policydecisions unleashed and supported an accelerated growth of finance. This enabled a shift to macroeconomic governance premised on 'easy credit', leading to political complacency regarding the risks and adverse consequences of excessive financial growth.

We are thus given a narrative of how political and economic transformations have reinforced one another, resulting in the kinds of predicaments and crises that Western capitalist societies are facing today (Streeck, 2014; Crouch, 2011). While this historical narrative is convincing and sustained by a rich body of evidence, it is less suitable for capturing how, in the current era, the very terms of interaction between politics, the state and the economy have changed (Konings, 2011; 2018). It is not only that governments increasingly rely on markets as privileged sites and vehicles for the provision of public goods (Morgan and Campbell, 2011). Financialization also involves a proliferation of regulations, governance frameworks and formal rules that have reconfigured capitalist modes of ownership and exchange, as well as structures of information and liquidity in markets (Carruthers and Stinchcombe, 1999; Baud and Chiapello, 2017). In contrast to the rhetoric of free markets and self-constrained government often associated with neoliberalism, we can thus observe how practices of governing, regulatory frameworks, and processes of market coordination become ever more entangled and aligned with one another, jointly re-defining the institutional foundations of contemporary capitalism (Carruthers, 2015).

In this article, we contribute to a genealogical perspective on how these alignments and entanglements have come about. We specifically demonstrate that innovations in finance, which at first challenged and disrupted post-war settlements, became successfully enlisted as constitutive features in a new macroeconomic governance regime. We suggest that this partly explains why political and regulatory support for financialization has proven so persistent and strong, despite the instabilities and inequities that have increasingly become visible as the dark side of excessive financial growth (Godechot, 2012, 2016; Lin and Tomaskovic-Devey 2013). While our approach accords with existing accounts emphasizing factors such as complacency, interest politics, ideology or capture, we want to demonstrate how these different factors are structurally amplified: policy makers also preserve the institutional foundations of financialized capitalism because it is on these foundations that their own governing 'capabilities' (Sassen, 2006) have come to rest.

Our empirical case in point is central banking. As noted by many scholars, central banks are key players in the historical transition to financialized capitalism. In many countries, they have supported the rise of finance and have enhanced their own institutional power as a result of this change (e.g. Jacobs and King, 2016). Central banking thus provides a particularly important and fruitful site for exploring how 'successful' alignments of particular forms of governing with economic processes have been achieved, and how these apparent successes have produced specific pathologies.

The first body of works to address this question were comparative institutionalist studies, which highlight central banks' prominent role in transitions from post-war Keynesian 
to neoliberal, pro-market regimes (Hall, 1986; Hay, 2001; Fourcade-Gourinchas and Babb, 2002). Despite the valuable comparative insights gained from these works, the heavy emphasis given to liberalization and de-regulation as key neoliberal policy recipes conflicts with more recent research that details how deliberate $r e$-regulation and market-making activities have laid crucial groundwork for financialized capitalism (Vogel, 1996; Haldane and Madouros, 2012; Thiemann, 2014; Baud and Chiapello, 2017). Analogously, the rather unequivocal association of 'neoliberal' central banking with monetarist hard money policies in the respective studies does not tally well with the recent historical record, especially central banks' increasingly accommodative stance towards credit-growth and prolonged periods of low interest rates to fend off crises (Schularick and Taylor, 2012).

Krippner's (2011) detailed case-study of the Federal Reserve's monetary policies after 1979 partly addresses these shortcomings. She provides a very persuasive narrative of how the evolution of (seemingly) contradictory policy measures by the Fed can be accounted for as part of a process in which the US state apparatus learned to exploit financialization as an unexpected solution to domestic distributional conflicts. However, by highlighting policy makers' motivations to escape these conflicts, Krippner underemphasizes how changes in the technical conduct of monetary policy during this period altered the very architecture of finance and redefined the sources of 'infrastructural power' (Mann, 1988; Braun, 2018a) upon which monetary policies rely.

Some promising advances in understanding the relations between central banking and financial markets have been made by organizational studies of central bank practices. For instance, several authors discuss the dominant role of economic expertise in central banks and the kinds of policies to which 'technocratic rationality' gives rise (Marcussen, 2009; Abolafia, 2012). Fligstein and colleagues (2017) link this literature to financialization by establishing cognitive reasons for 'regulatory neglect' and pro-market attitudes in central banks. They show that policy makers 'frame' market developments on the basis of neoclassical economics and thus ignore possible risks arising from financial inflation (see also Golub et al., 2014). While we also emphasize the crucial role played by different forms of expertise, we believe their impact on organizational practice should not be assessed apart from the 'material' (MacKenzie, 2017), operative linkages of monetary policy to the financial system. As we argue in more detail below, it is impossible to assess how 'technocratic' monetary policy is structurally implicated in the transformation of its 'ecology', the financial system, without closely attending to monetary policy implementation, its transmission, and the marketmaking that central banking entails.

Our article also diverges from the literature on regulatory capture, which draws attention to the continuing importance of revolving doors and other forms of collusion between central bankers and financial elites (e.g. Johnson and Kwak, 2010; Adolph, 2013; Kwak, 2014; Jacobs and King, 2016). We would argue that the commonness of such collusion points to more deep-seated alignments of central banks' institutional mandates and policy tasks with financial interests and rationalities that require assessment-particularly when trying to understand the structural implication of monetary policy in financialization.

With this study, we thus aim to move beyond analytic grids centered on free-market ideology and the power of sectorial interests, to look more closely at the concrete processes of 'organizing' - understood as 'ongoing efforts at coordination and control of activity and knowledge' (Cooren et al., 2011, p. 1149)—that have reconfigured structural relations between policy and market domains. To frame this analysis, we draw on approaches which 
problematize how such alignments between the political and other social fields are forged. We especially take up Rose's and Miller's insight that abstract 'programmes' of governing are indissociable from the concrete 'governing technologies' through which they are translated into practice. In Rose's and Miller's understanding, such technologies consist of 'strategies, techniques, and procedures' that are essential for rendering 'programmes operable' and through which 'a multitude of connections are established between the aspirations of authorities and the activities of individuals and groups' (Rose and Miller, 1992, p. 183).

Building on this idea, we argue that, to fully understand central banks' structural role in financialization, it is necessary to move beyond the all-too-common view of monetary policy as a process of selecting amongst a given set of technical instruments in pursuit of (sometimes conflicting) objectives defined by 'outside' forces such as (political) programmes, ideas or interests. We therefore suggest re-opening the 'black box' (MacKenzie 2005) created by a now accepted separation between monetary policy 'strategies' and their 'implementation' (Bindseil, 2004), in order to explore the critical role that central banks' technologies of governing play in 'organizing alignment' (Suchman, 2000) between programmes of governing and the market ecologies within which they are realized.

We explore two ways in which central banks' governing technologies perform this alignment-work. First, we analyze how formalizations of monetary policy practice rearticulate operative abstractions (such as the 'money supply' or 'inflation expectations') and order them into procedures and techniques, through which programmes of governing can be 'implemented'. Such processes of formalization are mediated by macroeconomic expert discourse which provides 'symbolic repertoires ... by which the structure of things is reset' (Knorr-Cetina 1999: 113), allowing central banks to (re-)articulate the financial system and the economy as governable fields of objects, in terms of which functional means-ends relations can be delineated (cf. Stinchcombe, 2001; Kallinikos et al., 2013). Technologies thus provide a crucial translation between programmes of monetary policy and the texture of financial activities through which they can operate. Organizing alignment in this way is the basis for constructing durable 'pragmatic regimes' that structure central banks' engagements with the world in terms of preassigned technical options (Thévenot, 2001). At the same time, such a pragmatic regime also black-boxes how the effectiveness of monetary policy becomes dependent on certain structural dynamics of the financial system that are inscribed in implementation and transmission processes. In the case of modern inflation targeting, this implies the exclusion of credit and fragile liquidity structures as relevant policy concerns (Borio and White, 2004).

Our second focus is on central banks' interventions in formally 'private' realms of markets. These interventions can take the form of market construction, e.g. when central banks respond to transformations in financial firms' prevailing techniques of liquidity management (Minsky, 1957) and actively contribute to the consolidation of these techniques into stable market routines. We draw attention to this market construction because it is one essential aspect of securing alignment between policy programmes and their implementation contexts. 'Successful' alignment is indicated by central banks' ability to steer short-term interest rates with ever more precision and consistency. But as a result of this 'success', central banks also become more strongly entangled with financial market processes. They become the anchors for the system's liquidity costs and reduce uncertainty over future access to liquidity, thereby fostering the wholesale borrowing/long-term lending practices that are the 
hallmark of contemporary, 'market-based' banking regimes (Adrian and Shin, 2008; Mehrling, 2011; Hardie et al., 2013).

In short, then, we argue that central banks' attempts to organize alignment of monetary policy with the changing structures of finance have drawn them into a kind of 'ontological complicity' (Bourdieu, 1981) with the dynamics of financialized capitalism. The pragmatic regime of 'inflation targeting' has given central banks effective means of policy implementation and transmission, and thus provided them with ample infrastructural power. But the flip-side of this alignment is that central banks have moved into a position as stabilizers and active supporters of financialization. Through their monetary policy, they reinsure fragile liquidity structures (Mehrling, 2011; Murau, 2017) and enable arbitrage along the yieldcurve (Borio and White, 2004; Adrian and Shin, 2008)—thus seemingly securing the 'governability' of contemporary capitalism against a backdrop of excessive credit-growth (Braun, 2018b).

We develop this argument historically, focusing on central banks' experimentation with novel techniques between the 'Great Inflation' and 'Great Moderation'-a period widely seen as critical for the consolidation of financialized capitalism and neoliberal regimes (Thelen, 1999; Streeck 2014). We show that the re-alignment between monetary policy and market structures during the period from 1979 to the late 1990s created a 'useful' (Millo and MacKenzie, 2009), but in crucial respects, problematic regime of monetary policy. Inflation targeting was constructed during those years as a formalization of monetary policy that black-boxes its own inherent entanglement with the dynamics of financial expansion. Due to central bankers' commitment to their new operative abstractions and formalizations, they developed a preference for market-based financial structures more conducive to inflation targeting techniques. This has led central bankers to emerge as key architects of a market-based, transnational liquidity regime (Gabor, 2016; Braun, 2018a).

We establish this historical argument through a comparative study of the USA and Great Britain. These countries count as early adopters, prototypes and promoters of financialized capitalism (see Helleiner 1994; Konings 2011; Krippner 2011; Green 2016). As Figure 1 shows, both countries experienced strong build-up of credit in their economies, beginning in the 1980s and picking up pace in the 1990s and 2000s. The widening gap we observe in both countries between the expansion of broad money (dashed lines) and credit (solid lines) indicates that this credit growth is increasingly due to market-based credit channels rather than traditional forms of credit intermediation through bank balance sheets. Measured as percentage of GDP growth during the same period, this indicates higher leverage ratios in the economy (Taylor 2015) that are sustained by more fragile structures of liquidity (Minsky 1986; Mehrling 2011).

We here concentrate on the role that innovations in money market techniques in the $1980 \mathrm{~s}$ and 1990s played in aligning macroeconomic policy with these financialization processes. For the US case, we draw on a wealth of technical and 'gray' literature by practitioners in which the work of rearticulating abstractions that align monetary governance with the structures of financial markets becomes visible and is reflected. Surprisingly, there has been much less interest in, and discussion of, money market techniques in Britain, even though radical changes in these techniques during the respective period crucially altered the nexus between macroeconomic policy and finance. For that reason, we investigate the British case by drawing on our own study of archival sources and on oral history interviews. 


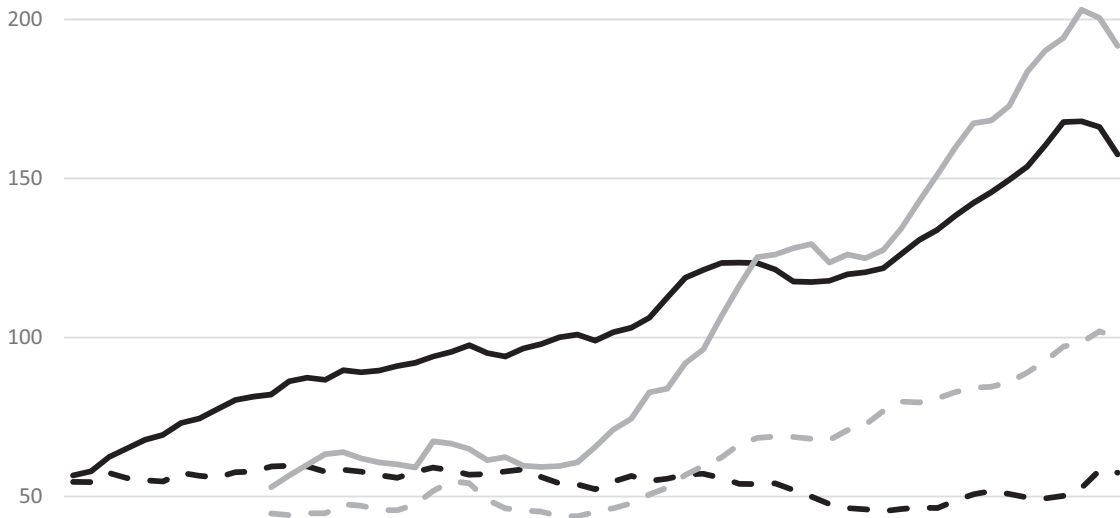
ฟू $\longrightarrow$ Credit/GDP US - - Broad money/GDP US Credit/GDP UK - - Broad money/GDP UK

Figure 1 Credit to private non-financial sector from all sectors at market value; domestic currency; adjusted for breaks (source: BIS total credit statistics). For GDP and broad money, we use data from Schularick and Taylor (2012) (see http://www.macrohistory.net/data/, last retrieved 29 October 2018).

Based on this evidence, we show that the Fed's 'bias towards excessive elasticity' in the provision of money market liquidity (Mehrling, 2011), and the role it subsequently played in fueling financial fragility, is not sufficiently explained by referring to the influence of (academic) ideas (as suggested in Mehrling, 2011), political accommodation (as argued in Krippner, 2011), or collusion with financial elites (as argued in Jacobs and King, 2016). Each of these explanatory factors can be shown to matter at different points in time and for different decisions taken. However, we argue that the overall trajectory and systematicity of the Fed's choices during this period are better explained as a sustained process of aligning conflicting programmatic political imperatives, particularly those of disinflation, financial stability and stable growth, with predominant expert opinions and the changing techniques of liquidity management employed by US banks. Through experimentation and accident, central bankers discovered that reconciling these conflicting imperatives required novel abstractions that would redefine the linkage between techniques of monetary governance and market structures through which Fed-policy works. As it turned out, these abstractions needed to prescind from credit growth and financial inflation for this new pragmatic regime to work.

The British case provides complementary insights on these processes because, still in the 1970s, we find a very different institutionalization of economic and financial governance in the UK, based on fragile compromises between the Keynesian state and the old City elite. 
The crisis in this regime then produced an extended period of conflict between the programmes, rationalities and technologies of governing which was not resolved, but rather aggravated, during the heydays of Thatcherite neoliberal reforms. Only in the 1990s did the Bank of England introduce operative abstractions into the conduct of macroeconomic governance which would align policy programmes with the changing structures of UK banking. This process also required a pro-active remaking of the very markets used for monetary policy implementation. The British case thus demonstrates particularly well that the operative, technical reconfigurations discussed in this article transcend the boundaries between what are usually understood as separate, public and private, realms.

We proceed as follows: we first analyze the US case and discuss the pivotal role played by Volcker in guiding monetary policy out of the 1970s dilemmas and into a world with elastic liquidity and low inflation (Section 2). We then discuss Great Britain as a complementary case, which allows us to demonstrate that the introduction of inflation targeting went hand-in hand with the wholesale endorsement of unfettered markets and thus implied a broader shift in institutional settlements between finance and the state (Section 3). We conclude our article with a comparative discussion of the insights gained from our two case studies. On this basis, we briefly develop the implications of our analysis for current discussions on regulating finance, and the role and shape of monetary policy in these efforts (Section 4).

\section{The Volcker shock as a 'critical experiment' for re-abstracting monetary policy}

Due to the global spread and dominance of US economics (Fourcade, 2006), both modern practice and theoretical reflections of central banking bear, in many ways, the traces of US historical experience and institutional evolution. Much as the Bank of England's policies in the 19th century, theoretical conceptions as well as operative abstractions derived from the Fed's experience have been inscribed not only into its own organizational structure, but also served as a template for 'proper' central banking worldwide (Bernanke and Woodford, 2006). 'Whiggish' narratives, depicting the evolution of central banking as linear technical progress, as well as more historically sensitive accounts that pay attention to processes of political contestation, tend to downplay this genealogy of what today appears as a given field of seemingly 'a priori' technical possibilities. Even Krippner's (2011) sublime and finegrained historical account of the Fed's role in financialization depicts the policy shifts between interest rate and monetary targets as motivated primarily by non-technical (political, legitimacy) concerns which strongly conditioned the choice between already preassigned technical options. What is lost from this analytical standpoint are the processes of realigning programmes of governing and their objects by rearticulating the field of abstractions (Stinchcombe, 2001; Kallinikos et al., 2013) in terms of which technical possibilities are delineated in the first place.

To develop such a focus on the articulation of technical possibilities, in this section of our paper, we want to focus on the Volcker experiment's role in setting the stage for the articulation of a novel pragmatic regime of monetary policy that brought it into alignment with the evolution towards unfettered financial markets. By tracing the genesis of the specific translation of political programmes through operative techniques that the Volcker experiment initiated, we are able to make visible how a symbiotic relationship with 
financialized market structures became inscribed into the very organizational practices of central banking.

This allows us not only to better understand the reasons for the Fed's complicity with financialization, but also provides a template for understanding how and why the transposition of US-style monetary policy into other contexts, such as the UK, required attendant modification in the broader structures of financial markets as the contextual conditions under which the respective monetary policy regime can work.

US monetary policy, both at the end of the 1970s and today, must be understood, at least in part, against the Fed's (long-standing) intellectual and operative adherence to the logic of 'free reserves targeting', dating from the 1920s and 1930s. The US financial system's evolution had been premised on market-based liquidity through the shiftability of assets (Mitchell, 1923; Mehrling, 2011). With refinancing and liquidity (in non-crisis conditions) dependent on a pool of scarce reserves (gold), banks were institutionally constrained to carefully gauge their longer-term costs of refinancing as a function of their present demand for scarce liquidity. Targeting 'free' or excess reserves (i.e. those not underpinning productive credit) thus constituted, in the view of the Fed, an effective nominal anchor constraining credit extension (Brunner and Meltzer, 1964, p. 52f.). As long as the extension of credit was endogenously constrained by the need to procure reserves, the tight integration of money and other financial markets meant that financial speculation directly fed into the (money market) interest rate, creating a potential control relation for monetary policy to exploit. The reasoning on which the use of this control relation rested was the following: A pool of 'free' reserves was necessary to fund initial speculation, before the higher (speculative) returns would translate into a higher demand for reserves and higher (money market) interest rate. This, in turn, would attract further reserves previously employed in other sectors, resulting in a cumulative process (until available reserves were exhausted). To break this cumulative process (and to prevent, first, the propagation of funding cost-push inflation through the economy, and finally the deflation that followed it), monetary policy thus needed to cut the link by which initial financial speculation attracted the reserves required for its own continuation from other sectors.

Thus, the core task for monetary policy was to stabilize the price of reserves (base money)—making 'smoothing' the interest rate the best option for achieving a nominal anchor for expectations (Dewald, 1963; Meltzer, 2009, p. 44; 75ff.; 196ff.). Interrupted by the New Deal and the enlisting of monetary policy for the management of federal debt during the war, the old framework was re-established by the Treasury-Fed Accord of 1951, guaranteeing the Fed's operational independence (Mueller, Jr, 1952). Until well into the 1970s, the distinctive logic of this original institutional context remained inscribed in the Fed's organizational practice.

However, after 1945, a misalignment emerged between the Fed's operative procedures and the market structures they sought to govern. As banks increasingly came to rely on the expanding and highly liquid Treasury markets to convert the 'overhang' of Treasuries that had resulted from war finance into cash reserves, the Fed became directly entangled with the day-to-day liquidity management of financial markets. Instead of exogenously adjusting the pool of reserves on which market liquidity ultimately rested, central banking thus became an endogenous provider of market liquidity itself (Meltzer, 2003, pp. 415-34) - a form of rollover overdraft facility. While smoothing the market interest rate to anchor markets' expectations of the cost of liquidity still worked reasonably well in the segmented financial system 
of the 1950s and 1960s, the discount rate (at which the Fed lends to financial markets) was increasingly becoming the true refinancing cost (Poole, 1982; Goodhart, 1989; Meltzer, 2009, p. 75f.). This meant that the nominal anchor that had enabled market participants to gauge their longer-term costs of refinancing as a function of their (expected) demand for liquidity was no longer provided by the institutional structure of the market. Banks' decisions on whether to extend credit to the economy, and thus ultimately creating inflationary pressures, ceased being anchored in an intertemporal horizon of effective realterm costs, instead simply tracking nominal variations in the refinancing conditions set by the Fed. The discount rate (at which the Fed backstopped the market) absorbed the market interest rate, whose role otherwise would have been to coordinate intertemporal allocation in real cost terms.

During the period of Keynesian demand management, this had the advantage of turning the interest rate into a direct lever for affecting growth and (un-)employment. However, with liquidity guaranteed by the Fed, and the incremental dissolution of the Glass-Steagall 'firewalls' (Funk and Hirschman, 2014), interbank markets for reserves deepened and widened, involving the Fed in an increasingly high-stakes game. The increasing integration of the financial system magnified the recessionary impulse from any attempt to discipline credit. As a result, the Fed was less and less able to enforce a nominal anchor against banks' assumption that refinancing liquidity would always be forthcoming (Mehrling, 2011). These contradictions moved to the surface during the 1970s (Meltzer, 1991, pp. 19-22). Experimenting with other quantity indicators than the increasingly irrelevant free reserves, the Fed found itself in a double bind: on the one hand, it would have needed to move the discount rate vigorously in order to credibly establish the threat of a nominal anchor. By enforcing a stable function between future refinancing conditions and today's credit extension, this threat could have imposed discipline and led banks to curtail current lending in anticipation of raising future costs of refinancing in the future. On the other hand, because monetary policy had become an endogenous interface of the markets' ongoing liquidity management, the Fed could not risk moving the federal funds rate in a way that would upset market stability. As a result, the Fed ended up with 'a money market rather than a monetary strategy' (Meltzer, 1991, p. 22) and watched as the economy slid into a cumulative process of inflation in which future (nominal) expected rates of return made it profitable to rely on the secure refinancing option provided by the Fed, in a form of system-wide arbitrage. ${ }^{1}$ In this institutional configuration, the central bank thus comes to underwrite a systemic arbitrage horizon in which low cost of liquidity (with no effective quantity constraint) at the backstop provided by the central bank fuels speculative dynamics. Unlike in the institutional context of the Fed's early years where speculation fed on 'free' reserves first, and the resulting increase in the (money market) interest rate created an arbitrage horizon with reserves employed in other sectors, in this brave new world smoothing the interest rate to cut off this

1 Working through Open Market Operations, as the Fed had done since the early stages of freereserves targeting, means, in effect, that monetary policy implementation works by manipulating the availability of liquidity in the short run, to affect the short-term interest rate. However, if financial institutions can count on being able to satisfy their needs for liquidity, in the mid- to long-run on an inter-bank market backstopped by the central bank, control over the short-end of refinancing costs does not readily translate into an effective constraint on the path of credit creation. 
mechanism no longer worked—and instead ended up fueling inflationary dynamics even further.

The Fed's failure to control inflation led to a situation where internal operative grammars (revolving around the technical difficulties just analyzed) became increasingly misaligned with external justificatory discourse about the purposes of monetary policy. Practitioners' technical debates on the problems of controlling inflation, arising from the endogeneity of the discount rate and the structures of market liquidity (Friedman, 1976), were increasingly drowned out by the widely debated Monetarist critique with its simplistic analysis and policy recipe based on the old quantity-theoretical adage that 'inflation is always and everywhere a monetary phenomenon' (Johnson, 1990[1971]). As Krippner shows, practitioners were intensely skeptical of the possibility of accurately controlling the money supply (Brimmer, 1990[1972]), but acquiesced to the pressure to adopt the idiom, eventually learning to appreciate its usefulness for cloaking unpopular policy choices (Krippner, 2011, p. 116ff.). But in focusing on how Monetarist tools proved 'serviceable' for political and tactical reasons despite their technical shortcomings, we miss their crucial role for tackling the endogeneity problem faced by monetary policy at the time-and eventually rearticulating it in the process. Because the interest rate was entangled in contradictory ways with multiple policy programmes and technologies, monetary policy's 'pragmatic regime' was paralyzed. Its entanglement with markets' liquidity management had dissolved the nominal anchor that could serve as a 'thermostat' (Krippner, 2011, p. 118) tightly coupling market decisions on credit to an intertemporally effective ('real') cost function; and any attempt to enforce such discipline through (very high) rates would-in addition to its macroeconomic repercussions-undermine the stability of financial markets.

While, in the short term, Monetarism proved useful as political cover for the high interest rate required to break inflation expectations, in the longer run it provided the technical frame required for a re-abstraction of monetary policy that integrated programmes, rationalities, and technologies into a durable pragmatic regime. Friedman's $(1966,1968)$ pathbreaking contribution charted a conceptual course for freeing the interest rate as a policy tool from its contradictory entanglements. He used the workhorse Keynesian IS-LM model to provide a diagnosis of the ongoing cumulative process as resulting from the endogeneity of market expectations. While Monetarism as a (political) programme aimed at a firmer control of the monetary base than practitioners thought technically possible, at the technological level it dovetailed nicely with more technical and operative critiques of monetary policy in the 1970s revolving around the so-called 'base drift' problem (Poole, 1979; Hetzel, 1981). For the reasons already discussed, the Federal Open Market Committee (FOMC) was generally reticent to tighten liquidity and instructed the Desk (the System Open Market Account Manager conducting the OMOs) 'to avoid a marked firming in money market conditions and unduly sharp increases in interest rates' (cited in Hetzel, 1981, p. 34). In line with the logic of excess or free-reserves targeting, the Fed thus sought to signal constraint by varying the price of (excess) reserves rather than pursuing an inflexible money supply target that could have disrupted markets. With the relation between targeted reserves and credit thus unstable (operational noise and lags muddying the waters), and the money supply only used as indicative, the Fed ended up adjusting its desired long-term target path for the money supply in line with the need to stabilize the (short-term) reserves path (and interest rate) - a practice that became infamous as 'interest rate smoothing'. As a result, the (short-term) interest rate and the money supply became entangled as operative targets, so that the 
consistency required for any of them to serve as an effective tool of monetary policy was 'compromised in order to arrive at mutually compatible targets' (Hetzel, 1981, p. 40).

As a mode of re-articulating monetary policy strategy and implementation, monetarism provided a form of abstraction that promised to resolve this conundrum. It suggested that it would be possible to disentangle the discount rate from markets' longer-term refinancing expectations and restore its function as an independent policy lever. By operatively tying its use to a background system of abstractions in terms of monetary quantities, its intended meaning could be affixed to the movements of and relations between these quantities. This would provide a firm and credible, exogenous nominal anchor for markets to decipher discount rate signals. Rather than directly constituting the effective costs of refinancing (allowing banks to simply track the nominal variations in the Fed's discount rate), the discount rate would indicate the longer-term, "real" costs of past and current expansion of creditmoney in terms of this background of monetary quantities (Hoover, 1984, p. 61f.; Patinkin, 1969). It is against this backdrop that the quantity-theoretical idiom could unfold its full performative power. Externally, it would help the Fed to signal and push through tougher policies, while also relieving the Fed of some of the blame for the consequences of antiinflationary policies, as it could present its own choices as readily following from the widely believed necessity of reducing an 'excessive' money supply. At the same time, internally, it would guide a process of re-articulating and re-aligning operative procedures and abstractions with market structures in a way that avoided the contradictions that had come to be tied to the short-term interest rate as policy conduit.

While this strategy emerged only gradually, Volcker's initial reform strategy in 19791980 already and astutely discerned and attempted to address the technical challenge of breaking out of the vicious circle of interest rate smoothing and base drift characteristic of the 1970s (Axilrod and Lindsey, 1981; Meltzer, 1991, p. 39). This meant giving 'greater emphasis to the supply of bank reserves' and less emphasis to 'confining short-term fluctuations in the federal funds rate' (Fed Press Release, 6 October 1979, cited in Meltzer, 1991, p. 39). Unable to 'control' the monetary base directly, the Fed needed a way to enact a long-term anchor against which banks could calibrate their expectations and (lending) decisions while threatening to impose actual costs on them in the event of their failing to do so (Hetzel, 1982, p. 238f.). To achieve this, Volcker instituted a complex and sophisticated shift in monetary policy procedures. This shift to 'non-borrowed reserves targeting' did not just represent a tactical embrace of monetarist language, as often suggested, but inscribed itself into the larger problématique just discussed (Brunner and Meltzer, 1983). Non-borrowed reserves targeting worked by projecting a (desired) overall money growth path. Considering how (recent) past volumes of bank borrowing had diverged from this projected path, the Fed would provide targeted short- and medium-term volumes of non-borrowed reserves through open market operations. Banks bidding for this pre-set volume of reserves would then allow the market to 'show through' in determining the (market) interest rate (Krippner, 2011, p. 121ff.), while the discount window remained open as a security valve and upper bound to the interest rate so that no actual, directly biting constraint was imposed. In this way, both the Fed and banks could observe whether, and by how much, the latter's balance sheet expansion was (in-)compatible with the Fed's desired reserve path. The (market) interest rate that emerged from this and the eventual volume of discount window borrowing thus could serve as indicators for both the Fed and banks to correct their decisions so as to achieve a smooth convergence on the desired path. 
The sheer complexity of this arrangement means that it is open to multiple interpretations. Whereas Krippner is interested in its 'serviceability' for political-tactical purposes, we have focused here on its usefulness in re-aligning the programmatic purpose of controlling inflation with technical procedures in a way that neutralizes the contradictions that arose from the previous mode of articulating programmes and (available) technologies of governing to market structures. Operative and technical debates revolved precisely around how this mechanism would allow the market to discover an adequate price for liquidity (Krippner's 'market-led interest rate') that was not directly overridden by the price that the Fed attached to its (ideally 'last resort') discount window facilities (Feinman and Poole, 1989). This would (in theory) free the bank rate as a policy tool from its direct entanglement with the financial system's refinancing operations. ${ }^{2}$ We can thus understand the Volcker experiment as an attempt-much like the Bank of England's later introduction of inflation forecasts-to install a virtual, procedural nominal anchor as the focal point for money market coordination. This anchor worked by virtue of sequencing. In the first stage, the Fed would establish the credibility of its fictional anchor by allowing interest rates to rise. Crucially, this credibility did not depend on actually imposing a biting liquidity constraint, but only on generating an observable price-effect as a consequence of more restrictive open market trading. Much like in the free-reserves doctrine, increased recourse to discount borrowing was thus seen as indicative of monetary restriction (Volcker, 1980). Subsequently, a smoothing of the federal funds rate would signal that, as much as the market had restrained its non-borrowed reserves demand to the Fed's liking, the Fed had successfully conveyed to market participants that it held this demand in check. Credibility tests recurred, and one of the primary concerns for the Volcker-Fed was to pass these tests (Goodfriend, 2007, p. 51). By disentangling the discount rate the Fed thus hoped to encourage an intertemporal calculation of refinancing costs as if a nominal anchor was in effect-and thus to tackle the twin problems of interest rate smoothing and base drift.

The price for making these abstractions work, however, was that the Fed had to stop worrying about credit growth. Monetarism thus proved useful to the extent that it provided a blueprint for disentangling the discount rate as a policy tool from market expectations regarding (longer-term) refinancing conditions, by creating a background of (interacting) monetary quantities as a nominal anchor for interpreting the signals sent via this lever. But as long as credit remained inscribed (by indicators of monetary growth) into the operative abstractions in terms of which the technologies of governing of this novel pragmatic regime were designed, its continued growth weakened the very control relations the Fed sought to exploit (Hetzel, 1982; Goodhart, 1986). In order to gain a robust functional relationship between policy lever and inflation, the substantive coupling to monetary quantities had to be abandoned. It was precisely the (eventually achieved) procedural separation of implementing the discount rate from the process of transmission, made possible by Monetarism, which set the stage for a gradual move towards a 'monetary policy without money' (Laidler, 2003). The Volcker experiment and its aftermath precisely illustrate the point that the price for having a technology that was effective in day-to-day operations was to decouple it operatively

2 Nor should direct regulations distort this price discovery process. Incidentally, this de-regulatory agenda dovetailed nicely with Monetarism's heavy emphasis on open-market operations as opposed to other policy tools such as reserve requirements. 
from the behavior of monetary quantities-although coupling it to them conceptually had paradoxically provided the initial inspiration for these operative reforms.

Though foreshadowing many of the abstractions integral to the inflation-targeting operative procedures that crystallized towards the turn of the following decade, the Volcker regime of 1979-1982 thus experienced some teething troubles. In particular, the coupling of the operative relation between the bank rate and inflation (expectations) to various quantitative variables and indicators as a means of representing the 'nominal anchor' directly within operative procedures conflicted with the goal of avoiding mechanical and disruptive restrictions of the money supply. The instability of the relations between money supply targets and required interest rates, as well as the technical difficulties of anticipating the effects of a given reserve supply on these rates, produced considerable noise and volatility (Hetzel, 1982, Meltzer, 1991). With markets failing to fully decode the Fed's new signaling regime (Cukierman and Meltzer, 1986, p. 69; Feinman and Poole, 1989), and financial innovation destabilizing many of the functional relationships presupposed by its operative procedures, the resulting mismatch of expectations produced a period of high and volatile interest rates (but equally volatile money growth rates) (Rosenblum and Strongin, 1983; Meltzer, 1991, p. 40). The ensuing scramble for reserves contributed to the already developing instability of the money demand function (Modigliani, 1988, p. 10). The higher liquidity preference and severe recession that followed from this 'Volcker shock' not only triggered a period of high real interest rates and contributed to an ongoing shift of accumulation from the real into the financial sector (Krippner, 2005). But it also shifted credit growth to speculative uses, manifesting itself henceforth primarily in financial inflation while inflation in the real economy fell precipitously. The Fed, even under Volcker, could not override the technical and operative constraints arising from its (acquired) role as a central hub in the structures of liquidity of the financial system, which up to this point had undermined any attempt to achieve a stable and robust functional transmission relationship between bank rate, quantities and market rate. However, the Fed got lucky. With credit growth manifesting itself in financial, not real-sector inflation, political pressure on the Fed to effectively constrain credit growth eased permanently. However, both within the logic of 'free reserves targeting' and the Fed's operative Monetarism of the Volcker era, monetary quantities were a constitutive element for the operative abstractions that guided monetary policy implementation. We must therefore look to developments at the level of technical abstractions and their linking into operative procedures for understanding the subsequent, and rather rapid, organizational 'forgetting' of the control of money and credit as instrumental to a central bank's mission.

The formalization of a 'monetary policy without money' was strongly favored by the operative-technical discussions surrounding the so-called 'Instrument-Target Problem' (Poole, 1970; Bindseil, 2004, p. 29ff.), debated in US monetary policy circles since well before Volcker's regime change. Having struggled with the entanglements of key operative variables analyzed above, central bankers became increasingly concerned with disentangling them in operational terms, and with developing instruments and techniques that allowed for stable and fine-tuned influence on operatively isolable targets (Goodhart, 1989, p. 314). Volcker's attempt to restore a robust operative relation by disentangling a signaling, shortterm interest rate from a long-term market rate that would incorporate a (virtual) longerterm nominal anchor clearly reflects these concerns. The Volcker shock had demonstrated the limits of this disentangling; as long as credit growth remained included in the functional 
relationships presupposed as conduits for policy implementation, the articulation of a durable and robust technology for governing financial markets remained illusory.

The 1982 switch to borrowed reserve targeting (Wallich, 1984), rather than being a simple return to interest rate targeting as is sometimes argued, amounted to an attempt to stabilize the interest rate and borrowed reserves levels (Goodhart, 1989, p. 326). However, this attempt to secure the monetary growth path without constantly disrupting the newly discovered stable relation between discount and inflation rates, failed. Serendipitously, the Fed had discovered in its operative practice another stable control relation that seemed to hold up after the switch to borrowed reserves targeting. Unexpectedly, the volatility of long-term interest rates had increased concomitantly with that of short-term rates during 1979-1982 (Spindt and Tarhan, 1987). Market expectations as to future inflation rates (as revealed in the term structure of the interest rate and the yield rates of government bonds) seemed to react increasingly sensitively to the Fed adjusting the short-term interest rate, while consumer price inflation, not least as a result of the Volcker shock recession and the resulting shift of credit into the financial sector (see Krippner, 2005), remained comparatively low (Hetzel, 2008 , p. xiv). In time, the Fed simply cut out the middleman (money) from of the operative procedures that had guided its operations for half a century, and focused directly on the covariation of the short-term rate and longer term market rates:

By 1983 , the Fed had reduced inflation to $4 \%$. However, as the decade progressed, it became clear that the nominal variable that disciplined FOMC actions was the bond rate not money. My colleague, Marvin Goodfriend, invented the phrase 'inflation scare' to describe how the FOMC treated discrete increases in bond rates as a challenge to its credibility. (Hetzel, 2008, p. xiv)

Though the Volcker framework itself had not produced a viable alignment of the programmes and technologies of government with the market structures through which they operated, it had installed a frame of abstraction which provided the basis for a reconfiguration of monetary policy that could. In trying to disentangle the short-term handling of liquidity provision operationally and conceptually from longer term considerations regarding the conditions of refinancing and prospects of returns, it had laid the foundations for a stable function to emerge between the Fed's manipulation of the bank rate and financial markets' reaction to it-a stability, however, which depended on monetary quantities being excluded from this conceptual and operative relationship. The Fed, despite legally remaining obliged to establish money growth targets, phased out operative and public reference to them beginning in the mid-1980s in response to the breakdown of viable instrument-target relations to exploit (Friedman and Kuttner, 1996, p. 79f.). Instead, it seized upon the opportunity and began to experiment with procedures for exploiting and strengthening the relation between the money market rates, the long-term rate, and inflation expectations. The same framework that had framed Volcker's attempts to isolate more clear-cut monetary control relations now contributed to justifying the Fed's quite abrupt and comprehensive abandonment of quantity targets. Over the next decade and a half, the Fed then worked on improving the precision of its techniques of controlling the short-term interest rate and finetuning its communicative interactions with financial markets. The new objective thus was to improve its ability to better exploit the influence it apparently had over these market expectations and thus, indirectly, over the inflation rate in the economy. The highly volatile shortterm interest rates of the early Volcker years had further pushed banks into active liability 
management and reduced their reliance on the Fed's short-term accommodation. In the longer run, liability management depressed demand for money to underpin credit expansion and thus also reduced the growth of the monetary base, at the cost of undermining its relation to nominal income and thus inflation. As a result, the policy rate was also freed from the task of actually constraining liquidity, removing one of the fundamental contradictions of pre-Volcker monetary policy. The Fed could instead increasingly use its rate as a pure signaling device, as Volcker had initially intended. ${ }^{3}$ This constituted only a small (operative) step for Fed practitioners-but a giant leap for theoretical conceptions of monetary policy that took a decade to develop a codified account of this new phenomenon (Bernanke and Mishkin, 1997). It allowed both the Fed and the markets to communicate to one another when inflationary expectations demanded a policy response and thus, gradually, to develop a joint game in which the Fed, in 'following the market' (Blinder, 2004), gained credibility in its eyes, thus reinforcing the market's sensitivities to its policy decisions. This enabled the Fed to 'observe' inflation expectations empirically and to react in setting the interest rate counter-cyclically and before the inflationary pressures indicated in bond markets manifested themselves, thus achieving precisely the (countercyclical), stable and robust feedback mechanism intended by the Volcker system from the beginning. The Monetarist experiment had thus achieved precisely the necessary form of abstraction at the operative level which subsequently permitted the central bank to conduct 'monetary policy without money' (Laidler, 2003).

\section{From Thatcherism to inflation targeting}

In the late 20th century, the Bank of England went through a radical transformation (Goodhart, 2004; Singleton, 2011). Rachel Lomax, who worked for HM Treasury in the 1970s and 1980s, remembers that, during her time as Treasury official, she experienced the Old Lady of Threadneedle Street as a 'very sleepy central bank' and 'quite peripheral to the main economic policy decision nexus in the UK'. ${ }^{4}$ But by the 1990 s, the central bank's position had changed. In this decade, the Bank of England emerged as a powerful macroeconomic policy maker with considerable international prestige. Rachel Lomax notes that, when she joined the central bank as Deputy Governor in 2003, 'I thought the institution had changed, almost beyond recognition'.

Scholars usually associate this development with Labour's decision to grant operational independence to the Bank of England in 1997 as well as an observed convergence in macroeconomic ideas (e.g. Tucker, 2018). But the Old Lady's new-won authority also had a less visible, 'infrastructural' source: From the early 1990s onwards, the British central bank had discovered how to effectively control interest rates and inflation expectations in an increasingly liberalized, transnationally networked financial system (Cobham, 2002; Tucker, 2004). The specific techniques used by the Bank came to resemble those of the Fed and provided the foundations upon which a new regime of macroeconomic management was built (Holmes, 2014).

3 In the new regime, it only mattered that rate variations affect expectations, thus cutting out the middle man of having to influence market expectations and decisions as to the adequate rate of (credit-)money growth.

4 Rachel Lomax, interview with authors, 5 April 2017. 
Tracing these developments will help us to better understand how a powerful nexus emerged in Britain between neoliberal policies and accelerations of financial growth. Most scholars go back to Thatcherism in order to narrate how these two trajectories became intertwined (Hall, 1986; Prasad, 2006; Davis and Walsh, 2016). And indeed, the years after 1979 constitute a critical juncture, when the parameters of politics, the structures of the financial system, and broader capitalist configurations changed. However, as argued below, Thatcherism resulted less in carefully planned, effective reforms, but in disruptive interventions that aggravated existing contradictions between the programmes, rationalities and technologies of British macroeconomic management. We therefore turn our attention to a less visible, protracted, but critical process of innovations in central banking techniques to show how a proper alignment between macroeconomic policies with financialized capitalism came about. More generally, what we aim to demonstrate with this case study is how a central bank not only introduced new tools of forecasting and communication to render expectations governable, but also co-created a system of market-based liquidity that facilitated policy implementation. This market-construction made a key contribution in tightening the nexus between inflation targeting and processes of financial growth.

In order to understand the radical overhaul of policy practices and market structures that this re-alignment entailed, it is important to recognize how distinctly British, entrenched institutional orders were gradually dissolved. From the Second World War onwards, the Treasury and Prime Minister held control over policy rates ('Bank Rates'), taking this authority away from a historically powerful central bank (Burnham, 2007). Another key aspect of the British situation was that, with high levels of post-war debt, active public debt management constituted a key, if not overriding task for the central bank (Allen, 2014). Moreover, for much of the 20th century, the Bank of England continued to operate its money market interventions via the market for 'bills' (government and commercial paper with different short-term maturities). In this market, Discount Houses (small institutions in the money market) were its primary counterparties. These market-making partnerships provided a kind of buffer between the central bank and the commercial banks. Internal market management was strictly separated from the London offshore (Eurodollar) and 'fringe' markets (Burn, 1999). Within the domestic, regulated realm, the Bank took a central role in liquidity provision, debt management, monetary policy implementation and regulation, while externally it refused to engage in either regulation, liquidity provision or lending of last resort (Moran, 1991; Schenk, 2004).

This post-war institutional configuration helped, for some time, to preserve the distinct features and interests of the City and regulated relationships between banking and the Keynesian state. However, starting in the 1960s and 1970s, different processes undermined this order. Outsiders entered UK banking and disrupted a sectorial structure still carefully guarded by the Bank; and new economic policy dilemmas emerged, as Britain faced several balance of payments crises, high inflation and reduced real growth (Fourcade-Gourinchas and Babb, 2002).

Initially, persistent institutional patterns shaped how British policy makers responded to these crises. In 1976, the central bank, with support from the International Monetary Fund, successfully pushed the Chancellor of the Exchequer to commit to monetary targeting (Needham, 2014a). However, in contrast to the USA, UK monetarism meant that the government would primarily use fiscal policy to achieve a restraint of overall domestic credit growth (Needham 2014a; Goodhart and Needham, 2017). In line with its traditional technologies of 
governing, the Bank of England contributed to these anti-inflationary efforts by exercising internal influence on the Chancellor towards austerity; it negotiated reserve requirements with clearing banks and, as a supplementary measure, imposed ceilings on wholesale borrowing. Interest rates were also raised at several points, but usually only in reaction to acute crises (e.g. on the foreign exchange or gilt market). Rate changes were difficult to engineer in the British system because these rates were controlled in the Treasury and thus set in consideration of debt management, Keynesian demand management, and the all-important mortgage rates. ${ }^{5}$ Therefore, official policy rates in the 1970s were kept below market rates, supporting a cumulative process of monetary and financial expansion that had been unleashed by the arrival of US-style liability management and term-transformation among British banks.

By the late 1970s, these predicaments of British economic policy had become all too obvious (Goodhart, 1986). The electoral victory of Margret Thatcher in 1979 was partly caused by this 'policy failure' and by her promise of radical change (Hall, 1986). Thatcher suggested that, while a rigorous Monetarism would end inflation, the liberalization of markets would turn Britain into a competitive economy again. In the course of the 1980s, we then observe a new pattern of economic development, marked by deindustrialization, credit-dependent growth and growing inequalities (Davis and Walsh, 2016). This has led many observers to ascribe a central role to Thatcher's neoliberal ideas in ushering in a financialized capitalist order.

However, when looking in more detail, it becomes evident that Thatcher's policy programmes were highly contradictory and that much of her government's early policy experimentation failed (Needham, 2014a; Prasad, 2006, pp. 102-120). One difficulty lay in conducting monetarism in the light of an unstable money demand function, which broke down earlier in the UK than the USA (Goodhart, 1989). During 1980, inflation rates began to drop, while demand for the key British monetary aggregate (M3) continued to rise (Needham, 2014a). Moreover, the economic and political costs of raising interest rates ever further, to reduce relentless money growth, seemed unbearable, even for a 'lady' who had publicly promised that she would 'not turn' (Needham, 2014a, pp. 144-155). Therefore, anti-inflationary interest rate policy was abandoned and the Conservatives returned to the monetarist fiscal policy that had already been tried by Labour in the period after 1976. Prasad calls this political maneuver 'Keynesianism in reverse' (2006, p. 118). A complementary series of Thatcherite experiments also remained unsuccessful. Monetarist extremists close to Thatcher had proposed a framework of monetary base targeting that would allow the government to eliminate 'excess liquidity' supposedly provided by the central bank in the course of its money market management. ${ }^{6}$ There would be strict limits on how much liquidity the central bank could provide to banks. But Bank of England officials successfully

5 'Under the current tap system, a rising trend in short-term rates appears to be liable to interrupt official sales of new debt (though it does not prevent piecemeal private sales of old debt on the secondary market). For when short rates appear to be on a rising trend, long rates also tend to rise; bond prices tend to fall, and institutional investors tend to delay purchases till prices appear to have reached bottom. The public deficit then has to be financed in other ways - by selling new Treasury bills.' (Dow and Saville, 1988, p. 135)

6 By the late 1970s, and more so in the early years of Thatcher, some influential monetarists-proponents of so-called monetary base control (e.g. Gordon Pepper, Karl Brunner, Allan Meltzer)-argued that the Bank of England's money market operations were the key reason for Britain's monetary ills because (a) unless the central bank controlled its own supply of money, the money supply could never be properly controlled; (b) necessary rate changes were often delayed for political reasons; 
mobilized against this 'attack' on established procedures. The compromise reached between Thatcher, the Treasury and the Bank was to introduce more minor operative changes, such as a shift from discount window lending to open market operations. But even these minor changes failed to have the intended effects. Indeed, monetary experts would later regard the Thatcherite reforms as posing a major obstacle on the way to re-align the programmatic imperatives of monetary policy with the financial sector structures upon which monetary policy implementation relied (Tucker, 2004). ${ }^{7}$

With their promise to introduce rigorous monetary policy, Thatcherites had thus failed to bring together their anti-inflationary programmatic goals with the technologies of money market management into a durable pragmatic regime. But this does not mean that the disruptive politics during the Thatcher era remained without effect (Beckett, 2016). Indeed, by aggravating the internal contradictions between political aims (i.e. disinflation), monetarist programmes and the available techniques of monetary management, Thatcherites unwittingly induced processes of re-alignment between policy techniques and financial market structures that would eventually generate an entirely new macroeconomic governance regime. Just like in the USA, economic crisis played an instrumental role in these processes. A brief period of high interest rates not only led to punitive corporate borrowing costs; but it also supported the rise of the exchange rate, which further reinforced a recessionary trend. Also, in 1981, in the midst of the slump, the Chancellor Geoffrey Howe increased taxes (Needham, 2014b). These were pro-cyclical policies without consistency; but they 'succeeded' in bringing down inflation by depressing economic activity overall. In even stronger contradiction to its money-control claims, Thatcher also helped with financial sector expansion by starting a process of deregulation (Offer, 2014). Her government abolished exchange controls, reserve requirements, and special supplementary deposits. Also, clearing banks were now allowed to enter the increasingly important market for mortgages as much as building societies were permitted to become banks. The technically more astute officials in the Treasury and central bankers were aware that these decisions ran counter to the Government's proclaimed intention to reduce the money supply (as set out in the "Mediumterm Financial Strategy") as they unleashed another wave of credit expansion (much to the dislike of 'believing' monetarists; see Pepper and Oliver, 2001). But by reinforcing a process of deindustrialization and accelerated financialization, Thatcherism eliminated the option of returning to the technologies of macroeconomic and financial management employed during the post-war period (Muellbauer, 1990; Offer, 2014), thereby setting a new context for subsequent attempts to align the new, neoliberal programmes of governing with the market ecologies in which they were to be implemented.

(c) the Bank of England acted as a lender of first resort, failing to impose any kind of discipline on the banks.

7 'The modifications to monetary control arrangements introduced last August [1981, Iw] were designed, inter alia, to provide for more flexible management of short-term interest rates allowing for greater degree of market influence and a lower political profile than with MLR [the Bank of England's discount lending rate, Iw], in the hope that this might reduce any "bias to delay" in more rigorously administered arrangements [...] The arrangements have not functioned as originally envisaged for two important reasons [...] Persistent money market shortages and the resulting rigidity of our dealing rates has meant much less 'noise' than expected [Second,] political interest in the precise levels of base rates seems certain to persist.' (Unknown BoE staff to Fforde and Coleby, Undisclosed band, 22 April 1982, BoE Archive 2A182/4) 
But if the contradictions between Thatcher's financial deregulation and her monetarism created formidable difficulties for this re-alignment, she also set parameters for the central bankers to find new solutions. One of her key contributions was to eliminate the regulation of credit from the purview of monetary governance. This regulation had been central to 20th century British monetary management, as emphasized in the reports of the MacMillan (1918) and Radcliffe Committees (Sayers, 1976; Kaldor, 1982; Taylor, 2015, p. 317). For most of post-war period, credit ceilings had been used as the preferred approach for restraining credit growth; but these had been abandoned in 1971. As mentioned above, with a politically constrained interest rate policy and ineffective reserve regulations, the authorities had been unable to tame accelerating credit expansion during the 1970s. Once in power, monetarists suggested that they could resolve these difficulties with a new approach: The central bank would simply need to manage its own balance sheet and thereby control credit-money creation at its source. In the event, market operations indeed became the central bank's key intervention tool as reserve requirements and restrictions on wholesale borrowing were dropped. But as much as the idea of setting targets for the central bank's balance sheet was abandoned in the early 1980s, so credit supply gradually disappeared from the political agenda. The experience of reduced consumer price inflation and strong growth in private credit suggested to the government that inflation could be 'conquered' in disregard of credit. Accordingly, even if monetarism had initially been proposed as a strategy for tackling money and credit as inseparable phenomena, its 'rhetorical' use during the Thatcher years paved the way for the kind of 'monetary policy without money' (Laidler, 2003) already described for the US case.

This shift in the politics of money, together with transformations in British banking towards financial agglomerates operating across markets and using active liability management, thus defined the broader context within which policy techniques and market ecologies would become realigned. For instance, within an increasingly deregulated banking sector, the Bank could no longer rely on segregated, cartel-like 'clubs' of market participants in order to influence broader processes in financial markets (Michie, 2004). The first to be affected by this change were the Discount Houses, who had been the Bank of England's most important counterparties. Within increasingly 'Americanized' money markets, these companies came to play a marginal role. The market managers at the central bank reacted to this change by adopting a new technique, which linked monetary policy implementation directly to the active liability techniques of commercial banks. The central bankers demanded that banks predict their daily shortages in central bank (i.e. final settlement) money so that the central bank could calculate with some precision how much daily liquidity support was needed. The central bank, in turn, published its own daily forecast of system shortages in its own liability via Reuters, thereby signaling its intended operations for the day to a broad group of market participants. It was precisely because banks only maintained marginal buffers of central bank money (increasingly framed as a 'tax'), and because financial firms developed systems for economizing on liquidity (sometimes upon pressure from the Bank), that such daily predictions and marginal accommodation proved relatively effective. Most importantly, within this system of marginal accommodation, the central bank could effectively influence interest rates even without institutional control over its counterparties (i.e. the Discount Houses) or over derivative forms of liquidity (e.g. wholesale borrowing). ${ }^{8}$

8 In an enthusiastic report about the central banks' ability to control short-term rates, experts from the Bank for International Settlements concluded in the late 1980s: 'Money market policy has ... 
These learning processes in the wake of Thatcher's disruptive politics prepared the ground for more strategic attempts, in the 1990s, of aligning British monetary policy with a transnationally integrated system of money and capital markets. This meant turning away from monetary aggregates or the exchange rate to the price of credit. Evidently, interest rates had always played a prominent role in the conduct of economic and monetary policy. But it had been difficult to predictably relate changes in long-term rates to the short-term policy rates decided by the government and steered by the central bank. For instance, a hike in short-term rates could induce higher long-term rates as participants expected more hikes to follow; or a short-term rate hike could induce a reduction in long-term rates, as market expectations of future inflation came down. ${ }^{9}$ This ambiguity, together with the political pressures already mentioned above, had made it difficult to establish unequivocal monetary policy criteria guiding the decisions taken in the Treasury. But financial innovations together with policy learning inside the Bank of England played a crucial role in resolving these ambiguities. In particular, active trading in futures allowed the central bank to identify expectations about future short-term rates that prevailed at any particular point. This enabled the central bank to observe how markets responded to monetary policy decisions and develop abstractions that disentangled changes in inflation expectations and expected future policy rates from other factors. Shaping these financial market responses and expectations gradually became the primary objective for the central bank.

For that purpose, in the course of the 1990s, the Bank of England introduced two critical innovations. First, after Britain's involuntary exit from the European Exchange Rate Mechanism (ERM) in September 1992, the HM Treasury and the Bank decided to publish regular Inflation Reports as a critical element of a new inflation targeting regime (Cobham, 2002; Holmes, 2014; Braun, 2015). These reports not only indicated whether the policy makers were on or off target with respect to the intended level of inflation. They also committed the policy makers to a forecast-based 'rule' that they intended to follow in their policy conduct. Whenever the forecast signaled an overshoot of the target (set by the Chancellor of the Exchequer), the market could expect an imminent rise in the policy rate; in the words of central bankers, the credibility of monetary policy from now on depended on 'whether private sector expectations of future inflation are consistent with the stated aim of [our]

assumed a larger role in recent years as reliance on direct credit and interest rate controls in domestic monetary management has declined and as financial markets have become more integrated internationally [...] Short term interest rates now play an important role as operating objectives in nearly all G-10 countries. Increased flexibility in short-term interest rates has come to be seen mainly as a way of adapting interest rate oriented money market policies to cope with shocks in the economy, volatility of expectations in the private financial markets and exchange market pressures [...] The central bank's ability to control short-term interest rates fundamentally depends on its capacity to ensure that the banking system can be induced to call upon it for marginal accommodation.' (Kneeshaw and Van Den Bergh, 1989, pp. 9-14)

9 The yield curve can be deciphered with the expectations theory of the term structure of interest rates. According to this theory, changes in long rates are interpreted as alterations of expectations regarding the future short-term rates that, in turn, reflect alterations in inflation forecasts that require a policy response. Such deciphering is conditioned on the assumption that policy makers and market participants would have a model for how to dissect these market rates into three different components-the real rate, the inflation risk premium and the expected inflation rate (Goodfriend, 1998). This model has questionable empirical validity (Blinder 2004). 
strategy' (Bank of England, 1993). To be sure, the reports initially also had another purpose, namely to inform negotiations between the Chancellor of the Exchequer and the Bank's Governor (in the so called "Ken and Eddie show"), the former of which still held formal authority over the Bank Rate. However, it soon became clear that, with the Inflation Reports, the central bank could mobilize the markets in augmenting its own institutional power vis-àvis the Treasury. For instance, if the Chancellor wanted a more expansionary monetary policy than Bank officials, this brought him into conflict not only with the increasingly sophisticated economic assessments produced by Bank officials, but also with market expectations, which were conditioned by the central bank's reports. In a sense, then, the decision taken in 1993 to conduct monetary policy through the management of market expectations was logically followed by the decision, in 1997, to give operational independence (authority over the interest rate decisions) back to the Bank.

A second, less recognized, but equally important innovation consisted in promoting a repo market in gilts-that is, a market for short-term lending collateralized with government debt. The Bank supported this development because managing market expectations via interest rates required ample liquidity and its 'shiftability' (Mehrling, 2011), so that rate changes are rapidly transmitted to other markets and the economy as a whole. ${ }^{10}$ The Bill market, which had traditionally served the Bank for implementing monetary policy, failed on these criteria, because it contained only a limited number of participants and complex rules of underwriting. Repo, in contrast, had already emerged in the USA and some parts of Europe (particularly France) as an integral part of the global liquidity structures upon which the banking and shadow banking system relied (Gabor, 2016). The Bank of England thus actively helped in linking the British domestic markets to these global liquidity structures, thereby installing the prerequisites for its inflation targeting regime.

Thus, after crucial changes had been brought about through the Thatcherite 'messy compromises' (Tucker, 2004), over the course of 1990s, British central bankers found ways of conducting monetary policy and bolstering their infrastructural power with the help of market-based finance. More specifically, the introduction and refinement of inflation targeting implied the fostering and strengthening of money markets in Britain that had emancipated from post-war institutional settlements and came to occupy a central position in a financialized configuration. At the time, central bankers were conscious of this coconstitution and the structural shift in the Bank of England's role towards finance. As one of the architects of the new regime states:

From the kind of interest in developing the effectiveness of the markets, obviously came the broader interest in macro-prudential stability $[\ldots]$ We were certainly conscious that with extensive international operations taking place in London, if there was a kind of crisis, they would be looking to us for liquidity provision. ${ }^{11}$

10 Gabor (2016) tells an incomplete version of this story; she argues that the Bank opposed these developments. But from the mid-1990s, key Bank of England officials encouraged banks to start a repo market in sterling.

11 Ian Plenderleith (interview with author, 7 May 2017), former head of market operations and member of the Bank of England's Monetary Policy Committee. With an another money market management reform in 2004, the Bank of England further strengthened its ties with market-based banking, by trading directly with, and providing its Discount Window facility (with a penal rate and repo-haircuts) to, an ever larger group of money market participants (Tucker 2004). 
In other words, central bankers in the 1990s allegedly acknowledged that operating monetary policy through the sterling repo-market extended the 'shiftability' of central bank liquidity and brought with it new responsibilities for the Bank of England as lender of last resort. But if dealt with at all, these entanglements between monetary policy with regulatory issues were discussed informally, not as explicit features of an increasingly formalized policy regime that promised highly selective and predictable engagements with the broader market ecologies. To be sure, this situation changed after the crisis of 2007-2008, when ensuring financial stability became an explicit policy mandate for the Bank of England. However, this mandate is explicitly separated from the conduct of monetary policy, and dealt with by the Financial Policy Committee. As we discuss below, this separation facilitates a persistent 'strategic ignorance' (McGoey, 2012) for deeper entanglements between financialization and inflation targeting regimes.

\section{Discussion and conclusion}

With our case studies of the changes in the Fed's and the Bank of England's operational regimes during the 1980s and 1990s, we seek to draw attention to the slow and uneven, but deeply consequential processes through which monetary policy became a constitutive part of financialized capitalism. We have used these cases as analytical prisms, which together highlight the core dimensions of this alignment: the articulation of abstractions which organize the alignment of the political and economic, and the redrawing of a field of practices where central banks and market participants can 'successfully' coordinate and interact. These shifts have yielded a pragmatic regime of modern monetary policy ('inflation targeting') whose durability and internal coherence depend on its complicity with excessive financial growth.

Historically, the Fed's monetary policy had already been entangled with a protean form of market-based liquidity that has become a constitutive feature of contemporary finance (Gabor, 2016; Murau, 2017). The US case thus demonstrates the struggle to articulate a viable grammar and working abstractions allowing the Fed to align monetary policy with an ongoing transformation of financial markets, with the resultant pragmatic regime embedding the Fed's monetary policy firmly as a constitutive part of the 'institutional foundations' of financialized capitalism (Carruthers, 2015). The Bank, in contrast, was faced with a more profound misalignment of macroeconomic policy and financial markets, requiring a gradual inscription of a new policy regime into the emerging structures and practices of liquidity management (which were, to a considerable degree, shaped by the USA). After disruptive changes during the Thatcherite period, the Bank eventually articulated its own version of this alignment that would, under the name of inflation targeting, subsequently spread around the globe.

If we have gone rather deeply into the technical heart of the matter, we did so to strongly push what for us constitutes an absolutely crucial point: namely, that central banks have not only—recursively—supported the rise of finance through particular policy decisions, but also have become constitutively entangled with, and thus part of, its institutional foundations.

This analytic perspective on the nexus between central banking and finance has implications which reach beyond the historical question of how to adequately describe the evolution of Anglo-Saxon monetary policies during the period discussed in this article. Once we have fully realized the extent to which 'modern' monetary policy is constitutively entangled with financialization, we can also better contextualize and evaluate the limits and contradictions 
of post-crisis reforms. We would like to stress, in particular, that in pointing to the durability and inertia of such alignments once they are achieved, our analysis helps to explain the resilience of market-based policy solutions within macroeconomic and financial governance, after a series of crises seemed to have proven inherent contradictions in this neoliberal regime (Braun, 2018a). Our article also provides analytical tools for explicating and criticizing the presuppositions of contemporary reform efforts-presuppositions which, as our analysis shows, result from a deep 'ontological complicity' (Bourdieu, 1981) between contemporary conceptions of governance and the structures within which they (seem to) 'succeed'.

The 'monetary policy without money' (Laidler, 2003) whose emergence we analyze in this article embeds central banks in financial markets in a way that allows a 'useful' (Millo and MacKenzie, 2009) mode of governing through day-to-day liquidity and expectation management - but at the cost of impotence towards financial markets' fundamental problems of unstable liquidity and fragile solvency. The net result, succinctly analyzed by a number of highprofile and widely discussed contributions, has been that central banks have slipped into a role of reinsurer of systemic risk and market-maker of last resort (Borio and White, 2004; Mehrling, 2011), backstopping the value of a widening pool of (only seemingly) 'liquid' assets.

By way of illustration of this point, a growing number of scholars have documented central banks' continuing commitment to deepening market-based finance and supporting the consolidation of a global market liquidity regime (Gabor, 2016; Gabor and Ban, 2016). For instance, Braun (2018a) gives an interesting account of how European central bankers defended securitization and actively fostered a further growth in repo-credit. Our article makes clear why central bankers seem so attached to this particular version of finance: their entire edifice of monetary policy, and hence their authority as policy makers, rests on a structural alignment with the respective markets, and remains tied to the operative abstractions and the formalizations in terms of which the technical possibilities for monetary policy are expressed. This problem is also reflected in the practice of 'unconventional' monetary policy observed since 2008, which constitutes not so much a (temporary) return to an older form of 'hydraulic' economic policy (cf. Braun, 2018b) or a direct attempt to subsidize finance (Jacobs and King, 2016). Rather, through quantitative easing, central bankers have sought to safeguard and restore the technical presuppositions of inflation targeting which we have analyzed in depth.

Along very similar lines, and no less controversially, efforts to construct a regime of macro-prudential regulation (Coombs, 2017) do not fundamentally question the entanglement of monetary policy in the structural mechanisms enabling financial inflation and fragility. We are certainly not in a position, nor do we want, to judge the technical workability of macro-prudential regulation in general. But what we can say is that, instead of addressing the deep entanglements between monetary policy and financialization, 'macropru' primarily seeks to install a corrective within banks' own risk management for the purpose of dissociating the ongoing process of financialization from the more specific problems of banking system failure ('saving banks from the financial cycle') (Borio, 2014). The underlying assumption of this 'resilience'-approach is that by increasing the transparency of risks (e.g. through stress tests), raising buffers and facilitating 'efficient' risk sharing within the financial system, systemic risk can be mitigated or even neutralized. As such, 'macropru' seeks to mitigate the symptoms of financialization by working through and around the institutional set-up that produces them in the first place-and may end up being overwhelmed by the symptoms of an underlying mechanism of which central banking has become an unsuspecting part. 


\section{Acknowledgements}

We are grateful for helpful comments from the two anonymous reviewers and from Gregory Jackson. The article has also greatly benefited from suggestions and comments made by the participants of the workshops 'Cultures of modeling' (München, February 2016) and '(Re-)Politicizing central banks and central bank independence in post-crisis financialized capitalism' (Weimar, June 2017). We also received useful feedback at the SASE Annual Meeting in Lyon, and at the 'Finance and Society' Conference in London (both in 2017). Finally, Timo Walter would like to extend a special thanks to Oliver Kessler for his support.

\section{Funding}

Research for this article was supported by a Christoph-Martin-Wieland fellowship from the University of Erfurt.

\section{References}

Abolafia, M. Y. (2012) 'Central Banking and the Triumph of Technical Rationality'. In Knorr Cetina, K. and Preda, A. (eds) The Oxford Handbook of the Sociology of Finance, Oxford, Oxford University Press, pp. 94-114.

Adolph, C. (2013) Bankers, Bureaucrats, and Central Bank Politics. The Myth of Neutrality, Cambridge, Cambridge University Press.

Adrian, T. and Shin, H. S. (2008) 'Financial Intermediaries, Financial Stability, and Monetary Policy', Staff Report, Federal Reserve Bank of New York, No. 346.

Allen, W. A. (2014) Monetary Policy and Financial Repression in Britain, 1951-59, Basingstoke, Palgrave Macmillan.

Axilrod, S. H. and Lindsey, D. E. (1981) 'Federal Reserve System Implementation of Monetary Policy: Analytical Foundations of the New Approach', American Economic Association, 71, 246-252.

Bank of England. (1993) 'Inflation Report', Bank of England Quarterly Bulletin, Spring, 3-45.

Baud, C. and Chiapello, E. (2017) 'Understanding the Disciplinary Aspects of Neoliberal Regulations: The Case of Credit-Risk Regulation under the Basel Accords', Critical Perspectives on Accounting, 46, 3-23.

Beckett, A. (2016) Promised You a Miracle: Why 1980-82 Made Modern Britain, London, Penguin.

Bernanke, B., and Mishkin, F. S. (1997) Inflation Targeting: A New Framework for Monetary Policy?, Cambridge, MA, National Bureau of Economic Research.

Bernanke, B. and Woodford, M. (eds) (2006) The Inflation-Targeting Debate, Chicago, IL, University of Chicago Press.

Bindseil, U. (2004) Monetary Policy Implementation, Oxford; New York, Oxford University Press.

Blinder, A. (2004) The Quiet Revolution: Central Banking Goes Modern, New Haven, Yale University Press.

Borio, C. (2014) 'Macroprudential Frameworks: (Too) Great Expectations?'. In Schoenmaker, D. (ed.) Macroprudentialism, London, VoxEU.org, pp. 29-45.

Borio, C. and White, W. R. (2004) Whither Monetary and Financial Stability? The Implications of Evolving Policy Regimes, BIS Working Papers, Basel, Bank for International Settlements.

Bourdieu, P. (1981) 'Men and Machines'. In Knorr Cetina, K. and Cicourel, A. V. (eds) Advances in Social Theory and Methodology: Toward an Integration of Micro- and Macro-Sociologies, London; Boston, Routledge \& Kegan Paul. 
Braun, B. (2015) 'Governing the Future: The European Central Bank's Expectation Management during the Great Moderation', Economy and Society, 44, 367-391.

Braun, B. (2018a) 'Central Banking and the Infrastructural Power of Finance: The Case of ECB Support for Repo and Securitization Markets', Socio-Economic Review (online first), doi: 10.1093/ser/mwy008.

Braun, B. (2018b) 'Central Bank Planning? Unconventional Monetary Policy and the Price of Bending the Yield Curve'. In Beckert, J. and Bronk, R. (eds) Uncertain Futures: Imaginaries, Narratives, and Calculation in the Economy, Oxford, Oxford University Press, pp. 194-216.

Brimmer, A. (1990[1972]) 'The Political Economy of Money: Evolution and Impact of Monetarism in the Federal Reserve System'. In Wood, J. C. and Woods, R. N. (eds) Milton Friedman. Critical Assessments, London, Routledge, pp. 95-106.

Brunner, K. and Meltzer, A. H. (1964) The Federal Reserve's Attachment to the Free Reserve Concept, Presented to the Subcommittee on Domestic Finance, Committee on Banking and Currency, US House of Representatives 88th Congress.

Brunner, K. and Meltzer, A. H. (1983) 'Strategies and Tactics for Monetary Control', Carnegie-Rochester Conference Series on Public Policy, 18, 59-103.

Burn, G. (1999) 'The State, the City and the Euromarkets', Review of International Political Economy, 6, 225-261.

Burnham, P. (2007) 'The Politicisation of Monetary Policy-Making in Postwar Britain', British Politics, 2, 395-419.

Carruthers, B. G. (2015) 'Financialization and the Institutional Foundations of the New Capitalism', Socio-Economic Review, 13, 379-398.

Carruthers, B. G. and Stinchcombe, A. L. (1999) 'The Social Structure of Liquidity: Flexibility, Markets, and States', Theory and Society, 28, 353-382.

Cobham, D. P. (2002) The Making of Monetary Policy in the UK, 1975-2000, Chichester; New York, J. Wiley.

Coombs, N. (2017) 'Macroprudential versus Monetary Blueprints for Financial Reform', Journal of Cultural Economy, 10, 207-216.

Cooren, F. Kuhn, T. Cornelissen, J. P., and Clark, T. (2011) 'Communication, Organizing and Organization: An Overview and Introduction to the Special Issue', Organization Studies, 32, 1149-1170.

Crouch, C. (2011) The Strange Non-Death of Neoliberalism, Cambridge, Polity Press.

Cukierman, A. and Meltzer, A. H. (1986) 'A Theory of Ambiguity, Credibility, and Inflation under Discretion and Asymmetric Information', Econometrica, 54, 1099.

Davis, A. and Walsh, C. (2016) 'The Role of the State in the Financialisation of the UK Economy', Political Studies, 64, 666-682.

Dewald, W. G. (1963) 'Free Reserves, Total Reserves, and Monetary Control', Journal of Political Economy, 71, 141-153.

Dow, J. C. R. and Saville, I. D. (1988) A Critique of Monetary Policy: Theory and British Experience, Oxford; New York, Clarendon Press; Oxford University Press.

Feinman, J. and Poole, W. (1989) 'Federal Reserve Policymaking: An Overview and Analysis of the Policy Process: A Comment', Carnegie-Rochester Conference Series on Public Policy, 30, 63-74.

Fligstein, N., Stuart Brundage, J., and Schultz, M. (2017) 'Seeing like the Fed: Culture, Cognition, and Framing in the Failure to Anticipate the Financial Crisis of 2008', American Sociological Review, 82, 879-909.

Fourcade, M. (2006) 'The Construction of a Global Profession: The Transnationalization of Economics', American Journal of Sociology, 112, 145-194.

Fourcade-Gourinchas, M. and Babb, S. L. (2002) 'The Rebirth of the Liberal Creed: Paths to Neoliberalism in Four Countries', American Journal of Sociology, 108, 533-579. 
Friedman, B. M. (1976) 'Targets, Instruments, and Indicators of Monetary Policy', Journal of Monetary Economics, 1, 443-473.

Friedman, B. M., and Kuttner, K. N. (1996) 'A Price Target for U.S. Monetary Policy? Lessons from the Experience with Money Growth Targets', Brookings Papers on Economic Activity, 77 ,

Friedman, M. (1966) 'Interest Rates and the Demand for Money', Journal of Law and Economics, 9, 71-85.

Friedman, M. (1968) 'The Role of Monetary Policy', The American Economic Review, 58, 1-17.

Funk, R. J. and Hirschman, D. (2014) 'Derivatives and Deregulation: Financial Innovation and the Demise of Glass-Steagall', Administrative Science Quarterly, 59, 669-704.

Gabor, D. (2016) 'The (Impossible) Repo Trinity: The Political Economy of Repo Markets', Review of International Political Economy, 23, 967-1000.

Gabor, D. and Ban, C. (2016) 'Banking on Bonds: The New Links between States and Markets', JCMS: Journal of Common Market Studies, 54, 617-635.

Godechot, O. (2012) 'Is Finance Responsible for the Rise in Wage Inequality in France?', Socio-Economic Review, 10, 447-470.

Godechot, O. (2016) 'Financialization Is Marketization! A Study of the Respective Impacts of Various Dimensions of Financialization on the Increase in Global Inequality', Sociological Science, 3, 495-519.

Golub, S., Kaya, A. and Reay, M. (2014) 'What were they Thinking? The Federal Reserve in the Run-up to the 2008 Financial Crisis', Review of International Political Economy, 1-36.

Goodfriend, M. (1998) 'Using the Term Structure of Interest Rates for Monetary Policy', Federal Reserve Bank of Richmond Economic Quarterly, 84, 13-28.

Goodfriend, M. (2007) How the World Achieved Consensus on Monetary Policy, Cambridge, MA, National Bureau of Economic Research.

Goodhart, C. (1986) 'Financial Innovation and Monetary Control', Oxford Review of Economic Policy, 2, 79-102.

Goodhart, C. A. (1989) 'The Conduct of Monetary Policy', The Economic Journal, 99, 293-346.

Goodhart, C. A. (2004) 'The Bank of England over the Last 35 Years', Bankhistorisches Archiv, Beiheft 43: Welche Aufgaben muss eine Zentralbank wahrnehmen? Historische Erfahrungen und europäische Perspektiven, 29-54.

Goodhart, C. A. E. and Needham, D. J. (2017) 'Historical Reasons for the Focus on Broad Monetary Aggregates in Post-World War II Britain and the "Seven Years War" with the IMF', Financial History Review, 24, 331-356.

Green, J. (2016) 'Anglo-American Development, the Euromarkets, and the Deeper Origins of Neoliberal Deregulation', Review of International Studies, 42, 425-449.

Haldane, A. G. and Madouros, V. (2012) 'The Dog and the Frisbee'. In Proceedings from the Economic Policy Symposium, Jackson Hole, Federal Reserve Bank of Kansas, pp. 109-159.

Hall, P. A. (1986) Governing the Economy: The Politics of State Intervention in Britain and France, New York, Oxford University Press.

Hardie, I. et al. (2013) 'Banks and the False Dichotomy in the Comparative Political Economy of Finance', World Politics, 65, 691-728.

Hay, C. (2001) 'The "Crisis" of Keynesianism and the Rise of Neoliberalism in Britain: An Ideational Institutionalist Approach'. In Campbell, J. L. and Pedersen, O. K. (eds) The Rise of Neoliberalism and Institutional Analysis, Princeton, NJ, Princeton University Press, pp. 193-218.

Helleiner, E. (1994) States and the Reemergence of Global Finance: From Bretton Woods to the 1990s, Ithaca NY, Cornell University Press.

Hetzel, R. L. (1981) 'The Federal Reserve System and Control of the Money Supply in the 1970s', Journal of Money, Credit and Banking, 13, 31. 
Hetzel, R. L. (1982) 'The October 1979 Regime of Monetary Control and the Behavior of the Money Supply in 1980', Journal of Money, Credit and Banking, 14, 234-251.

Hetzel, R. L. (2008) The Monetary Policy of the Federal Reserve: A History, Cambridge; New York, Cambridge University Press.

Holmes, D. R. (2014) Economy of Words: Communicative Imperatives in Central Banks, Chicago; London, The University of Chicago Press.

Hoover, K. D. (1984) 'Two Types of Monetarism', Journal of Economic Literature, 22, 58-76.

Jacobs, L. R., and King, D. S. (2016) Fed Power: How Finance Wins, New York, NY, Oxford University Press.

Johnson, H. G. (1990[1971]) 'The Keynesian Revolution and the Monetarist Counter-Revolution', In Wood, J. C. and Woods, R. N. (eds) Milton Friedman. Critical Assessments, London, Routledge, pp. 72-88.

Johnson, S. and Kwak, J. (2010) 13 Bankers: The Wall Street Takeover and the Next Financial Meltdown, New York, Vintage Books.

Kallinikos, J., Hasselbladh, H. and Marton, A. (2013) 'Governing Social Practice: Technology and Institutional Change', Theory and Society, 42, 395-421.

Kaldor, N. (1982) The Scourge of Monetarism. Oxford, Oxford University.

Kneeshaw, J. T. and Van Den Bergh, P. (1989) Changes in Central Bank Money Market Operating Procedures in the 1980s, Basel, Bank for International Settlements.

Knorr-Cetina, K. (1999) Epistemic Cultures: How the Sciences Make Knowledge, Cambridge, MA, Harvard University Press.

Konings, M. (2011) The Development of American Finance, New York, Cambridge University Press.

Konings, M. (2018) Capital and Time: For a New Critique of Neoliberal Reason, Stanford, California, Stanford University Press.

Krippner, G. (2005) 'The Financialization of the American Economy', Socio-Economic Review, 3, 173-208.

Krippner, G. (2011) Capitalizing on Crisis: The Political Origins of the Rise of Finance, Cambridge, MA, Harvard University Press.

Kwak, J. (2014) 'Cultural Capture and the Financial Crisis'. In Carpenter, D. and Moss, D. A. (eds) Preventing Regulatory Capture. Special Interest Influence and How to Limit It, Cambridge, Cambridge University Press.

Laidler, D. E. W. (2003) 'Monetary Policy without Money: Hamlet without the Ghost', Paper presented at a conference in honour of Charles Freedman, Bank of Canada, Ottawa, June 19-20th 2003.

Lin, K.-H. and Tomaskovic-Devey, D. (2013) 'Financialization and U.S. Income Inequality, 1970-2008', American Journal of Sociology, 118, 1284-1329.

MacKenzie, D. (2005) 'Opening the Black Boxes of Global Finance', Review of International Political Economy, 12, 555-576.

MacKenzie, D. (2017) 'A Material Political Economy: Automated Trading Desk and Price Prediction in High-Frequency Trading', Social Studies of Science, 47, 172-194.

Mann, M. (1988) The Sources of Social Power 1. A History of Power from the Beginning to A.D. 1760. Cambridge, Cambridge University Press.

Marcussen, M. (2009) 'Scientization of Central Banking: The Politics of A-Politicization'. In Dyson, K. and Marcussen, M. (eds) Central Banks in the Age of the Euro, Oxford, Oxford University Press, pp. 373-390.

McGoey, L. (2012) 'The Logic of Strategic Ignorance: The Logic of Strategic Ignorance', The British Journal of Sociology, 63, 533-576.

Mehrling, P. (2011) The New Lombard Street: How the Fed Became the Dealer of Last Resort, Princeton, NJ, Princeton University Press. 
Meltzer, A. H. (1991) 'The Fed at Seventy Five'. In Belongia, M. T. (ed.) Monetary Policy on the 75th Anniversary of the Federal Reserve System, Dordrecht, Springer Netherlands, pp. 3-65.

Meltzer, A. H. (2003) A History of the Federal Reserve, Volume I, 1913-1951, Chicago, University of Chicago Press.

Meltzer, A. H. (2009) 'A History of the Federal Reserve Volume II, Book One, 1951-1969', accessed at on October 2, 2012.

Michie, R. C. (2004) 'The City of London and the British Government: The Changing Relationship'. In Michie, R. C. and Williamson, P. (eds) The British Government and the City of London in the Twentieth Century, Cambridge, Cambridge University Press, pp. 31-58.

Millo, Y. and MacKenzie, D. (2009) 'The Usefulness of Inaccurate Models: Towards an Understanding of the Emergence of Financial Risk Management', Accounting, Organizations and Society, 34, 638-653.

Minsky, H. P. (1957) 'Central Banking and Money Market Changes', The Quarterly Journal of Economics, 71, 171.

Minsky, H. P. (1986) Stabilizing an Unstable Economy. A Twentieth Century Fund Report. New Haven; London, Yale University Press.

Mitchell, W. F. (1923) 'The Institutional Basis for the Shiftability Theory of Bank Liquidity', The University Journal of Business, 1, 334-356.

Modigliani, F. (1988) 'The Monetarist Controversy Revisited', Contemporary Economic Policy, 6, 3-18.

Moran, M. (1991) The Politics of the Financial Services Revolution: The USA, UK and Japan, London, Macmillan.

Morgan, K. J. and Campbell, A. L. (2011) The Delegated Welfare State: Medicare, Markets, and the Governance of Social Policy, New York, Oxford University Press.

Muellbauer, J. (1990) The Great British Housing Disaster and Economic Policy. Economic Study, London, Institute for Public Policy Research.

Mueller, F. W. Jr. (1952) 'The Treasury-Federal Reserve Accord', Journal of Finance, 7, 580-599.

Murau, S. (2017) 'Shadow Money and the Public Money Supply: The Impact of the 2007-2009 Financial Crisis on the Monetary System', Review of International Political Economy, 24, 802-838.

Needham, D. (2014a) UK Monetary Policy from Devaluation to Thatcher, 1967-1982, Basingstoke, Palgrave Macmillan.

Needham, D. (2014b) 'The 1981 Budget: “a Dunkirk, Not an Alamein'. In Needham, D. and Hotson, A. (eds) Expansionary Fiscal Contraction: The Thatcher Government's 1981 Budget in Perspective, Cambridge, Cambridge University Press, pp. 148-180.

Offer, A. (2014) 'Narrow Banking, Real Estate, and Financial Stability in the UK c. 1870-2010'. In Dimsdale, N. and Hotson, A. (eds) British Financial Crises since 1825, Oxford, Oxford University Press, pp. 158-173.

Patinkin, D. (1969) Money, Interest and Prices: An Integration of Monetary and Value Theory, New York, Harper and Row.

Pepper, G. T. and Oliver, M. J. (2001) Monetarism under Thatcher: Lessons for the Future. Northampton, MA: Edward Elgar.

Poole, W. (1970) 'Optimal Choice of Monetary Policy Instruments in a Simple Stochastic Macro Model', The Quarterly Journal of Economics, 84, 197-216.

Poole, W. (1979) 'Burnsian Monetary Policy: Eight Years of Progress?', The Journal of Finance, 34, 473.

Poole, W. (1982) 'Federal Reserve Operating Procedures: A Survey and Evaluation of the Historical Record since October 1979', Journal of Money, Credit and Banking, 14, 575.

Prasad, M. (2006) The Politics of Free Markets: The Rise of Neoliberal Economic Policies in Britain, France, Germany, and the United States, Chicago, University of Chicago Press. 
Rose, N. and Miller, P. (1992) 'Political Power beyond the State: Problematics of Government', The British Journal of Sociology, 43, 173-205.

Rosenblum, H. and Strongin, S. (1983) 'Interest Rate Volatility in Historical Perspective', Economic Perspectives, 7, 10-19.

Sassen, S. (2006) Territory, Authority, Rights: From Medieval to Global Assemblages, Princeton, NJ, Princeton University Press.

Sayers, R. S. (1976) The Bank of England 1891-1944, Volume 1. Cambridge, Cambridge University Press.

Schenk, C. R. (2004) 'The New City and the State in the 1960s'. In Michie, R. C. and Williamson, P. (eds) The British Government and the City of London in the Twentieth Century, Cambridge, Cambridge University Press, pp. 322-339.

Schularick, M. and Taylor, A. M. (2012) 'Credit Booms Gone Bust: Monetary Policy, Leverage Cycles, and Financial Crises, 1870-2008', American Economic Review, 102, 1029-1061.

Singleton, J. (2011) Central Banking in the Twentieth Century, Cambridge, Cambridge University Press.

Spindt, P. A. and Tarhan, V. (1987) 'The Federal Reserve's New Operating Procedures', Journal of Monetary Economics, 19, 107-123.

Stinchcombe, A. L. (2001) When Formality Works: Authority and Abstraction in Law and Organizations, Chicago, University of Chicago Press.

Streeck, W. (2014) Buying Time: The Delayed Crisis of Democratic Capitalism, Brooklyn, NY, Verso.

Suchman, L. (2000) 'Organizing Alignment: A Case of Bridge-Building', Organization, 7, 311-327.

Taylor, A. M. (2015) 'Credit, Financial Stability, and the Macroeconomy', Annual Review of Economics, 7, 309-339.

Thelen, K. (1999) 'Historical Institutionalism in Comparative Perspective', Annual Review of Political Science, 2, 369-404.

Thévenot, L. (2001) 'Pragmatic Regimes Governing the Engagement with the World'. In Schatzki, T. R., Knorr Cetina, K. and von Savigny, E. (eds) The Practice Turn in Contemporary Theory, London, Routledge, pp. 56-73.

Thiemann, M. (2014) In the Shadow of Basel: How Competitive Politics Bred the Crisis', Review of International Political Economy, 1-37.

Tucker, P. (2004) 'Managing the Central Bank's Balance Sheet: Where Monetary Policy Meets Financial Stability', Bank of England Quarterly Bulletin, Autumn, 359-382.

Tucker, P. Unelected Power: The Quest for Legitimacy in Central Banking and the Regulatory State. Princeton, NJ, Princeton University Press, 2018.

Vogel, S. K. (1996) Freer Markets, More Rules: Regulatory Reform in Advanced Industrial Countries, Ithaca, NY \& London, UK, Cornell University Press.

Volcker, P. (1980) 'Recent Developments in Monetary Policy', Federal Reserve Bulletin, 943-952.

Wallich, H. C. (1984) 'Recent Techniques of Monetary Policy', Federal Reserve Bank of Kansas City Economic Review, 69, 21-30. 